\title{
Spiders (Araneae) from the Alpine Zone of the South and West Flanks of Mt. Wrangell, Alaska $\left(62^{\circ} \mathrm{N}, 144^{\circ} \mathrm{W}\right)$ \\ BRUCE CUTLER $^{1}$ and RANSOM SALTMARCH ${ }^{2}$
}

\author{
(Received 5 March 1984; accepted in revised form 1 May 1985)
}

\begin{abstract}
A series of spiders was collected during a summer season from the alpine zone of Mt. Wrangell, Alaska $\left(62^{\circ} \mathrm{N}, 144^{\circ} \mathrm{W}\right) . \mathrm{Most}$ of the species collected have also been taken from lowland sites in the boreal forest and the Arctic and have extensive ranges in the northern nearctic. Some of these species also occur in the palearctic. The dominant families were the Linyphiidae (Erigoninae and Linyphiinae) and the Lycosidae, the only families represented by more than two species within a family. The other families represented were the Agelenidae, Araneidae, Dictynidae, Salticidae and Thomisidae. A phalangid and trombidiiform mite were also collected.
\end{abstract}

Key words: spiders, Mt. Wrangell, alpine zone, Alaska, nearctic and holarctic distribution

RÉSUMÉ. Une quantité d'araignées furent recueillies pendant l'été dans la zone alpine du mont Wrangell, en Alaska (62 $\left.\mathrm{N}, 144^{\circ} \mathrm{O}\right)$. La plupart des espèces trouvées ont aussi été prises dans des sites montagnards de la forêt boréale et dans l'Arctique et ont une vaste distribution dans le nord des régions néarctiques. Certaines des espèces sont aussi trouvées dans le paléarctique. Les familles dominantes furent les Linyphiidés (les Ergonidés et les Linyphiinés) et les Lycosidés. Elles furent les seules familles représentées par plus de deux espèces au sein d'une même famille. Les autres familles représentées furent les Agélénidés, les Aranéides, les Dictynidés, les Salticidés et les Thomisidés. Une mite phalangide et trombodiiforme fut aussi recueillie.

Mots clés: araignées, mont Wrangell, zone alpine, Alaska, région néarctique, distribution holarctique

Traduit pour le journal par Maurice Guibord.

In view of the enormous ecological and biogeographical importance of the region, it seems unfortunate that we know practically nothing of the high altitude insects of the Alaskan mountains. [Mani, 1968:393.]

\section{INTRODUCTION}

While the above quote by Mani refers to insects, it is clear from the thrust of his book that he included all terrestrial arthropods within his scope, and the quote is certainly applicable to the arachnids as well. In 1978 one of us (RS) made a solo expedition to study the biology and geology of the southern and western flanks of Mt. Wrangell, southeastern Alaska, approximately $62^{\circ} \mathrm{N}, 144^{\circ} \mathrm{W}$. Collections were made between 6 June and 22 July in the alpine zone. In 1980 an additional specimen was procured on a shorter trip to the region. A privately printed brochure (Saltmarch, 1978) provides details of the descriptive biology and geology and of the expedition. The Appendix lists the collecting sites by locality with habitat information. This detailed appendix is necessary for archival reasons, as it is unlikely that arachnids will be collected at any time in the near future in the area. The alpine zone as used in this paper refers to regions above the local treeline. Camps were pitched beside flowing water, thus accounting for bias toward stream or riverside collecting sites.

\section{METHODS}

Spiders were collected by handpicking or by sweeping vegetation. No attempt was made to be quantitative, the goal being to record the species present at the different sites and in different
TABLE 1. Alpine spiders from Mt. Wrangell

\begin{tabular}{|c|c|}
\hline Taxon & Collection Number \\
\hline \multicolumn{2}{|l|}{ Agelenidae } \\
\hline Cicurina species, immature male & S837 \\
\hline \multicolumn{2}{|l|}{ Araneidae } \\
\hline Aculepeira carbonarioides (Keyserling) & $S 839,52,54$ \\
\hline Hypsosinga groenlandica Simon & S826 \\
\hline \multicolumn{2}{|l|}{ Dictynidae } \\
\hline Dictyna major Menge & S835 \\
\hline \multicolumn{2}{|l|}{ Linyphiidae } \\
\hline \multicolumn{2}{|l|}{ Erigoninae } \\
\hline Baryphyma species male & S830 \\
\hline Ceraticelus crassiceps (O. P. Cambridge) & S837 \\
\hline Erigone species female & S4 \\
\hline Walckenaeria species male & S830 \\
\hline Undetermined female, eight immatures & $S 837,40,57$ \\
\hline \multicolumn{2}{|l|}{ Linyphiinae } \\
\hline Lepthyphantes alpinus (Emerton) & S837 \\
\hline L. washingtoni Zorsch & $S 826,30,35$ \\
\hline Pityohyphantes species female & S837 \\
\hline \multicolumn{2}{|l|}{ Lycosidae } \\
\hline Alopecosa aculeata (Clerck) & $\mathrm{S} 826,30$ \\
\hline Pardosa albomaculata Emerton & $\mathrm{S} 831$ \\
\hline P. furcifera (Thorell) & S826 \\
\hline$P$. groenlandica (Thorell) & 5833,50 \\
\hline$P$. hyperborea (Thorell) & S826, 34 \\
\hline$P$. palustris (Linnaeus) & $\mathrm{S} 830$ \\
\hline$P$. uintana Gertsch & S834 \\
\hline \multicolumn{2}{|l|}{ Salticidae } \\
\hline Chalcoscirtus carbonarius Emerton & S856 \\
\hline Thomisidae & \\
\hline Xysticus deichmanni Sörensen & S831 \\
\hline
\end{tabular}

\footnotetext{
${ }^{1} 1747$ Eustis Street, St. Paul, Minnesota 55113, U.S.A. 
habitats. Since each site was visited once, no pitfall trapping was attempted.

\section{DISCUSSION}

Table 1 lists the spiders caught by index number to location and habitat. At only three localities - S826, S830 and S837 were there as many as five species represented, and at only the first locality were three families represented. All three sites were densely vegetated near water.

General observations were that lycosids were abundant wherever vegetation occurred. The orb webs of Aculepeira carbonarioides (Araneidae), which occur in boulder fields and on cliff faces, were about $35 \mathrm{~cm}$ in diameter. One contained a captured crane fly (Tipulidae). The jumping spider Chalcoscirtus carbonarius (Salticidae) was abundant on one rock slide where there were numerous retreats; there were immature specimens as well as the females taken.

Of those 15 spider species for which reliable geographic data

TABLE 2. Geographical distribution of alpine zone spiders from Mt. Wrangell ${ }^{1}$

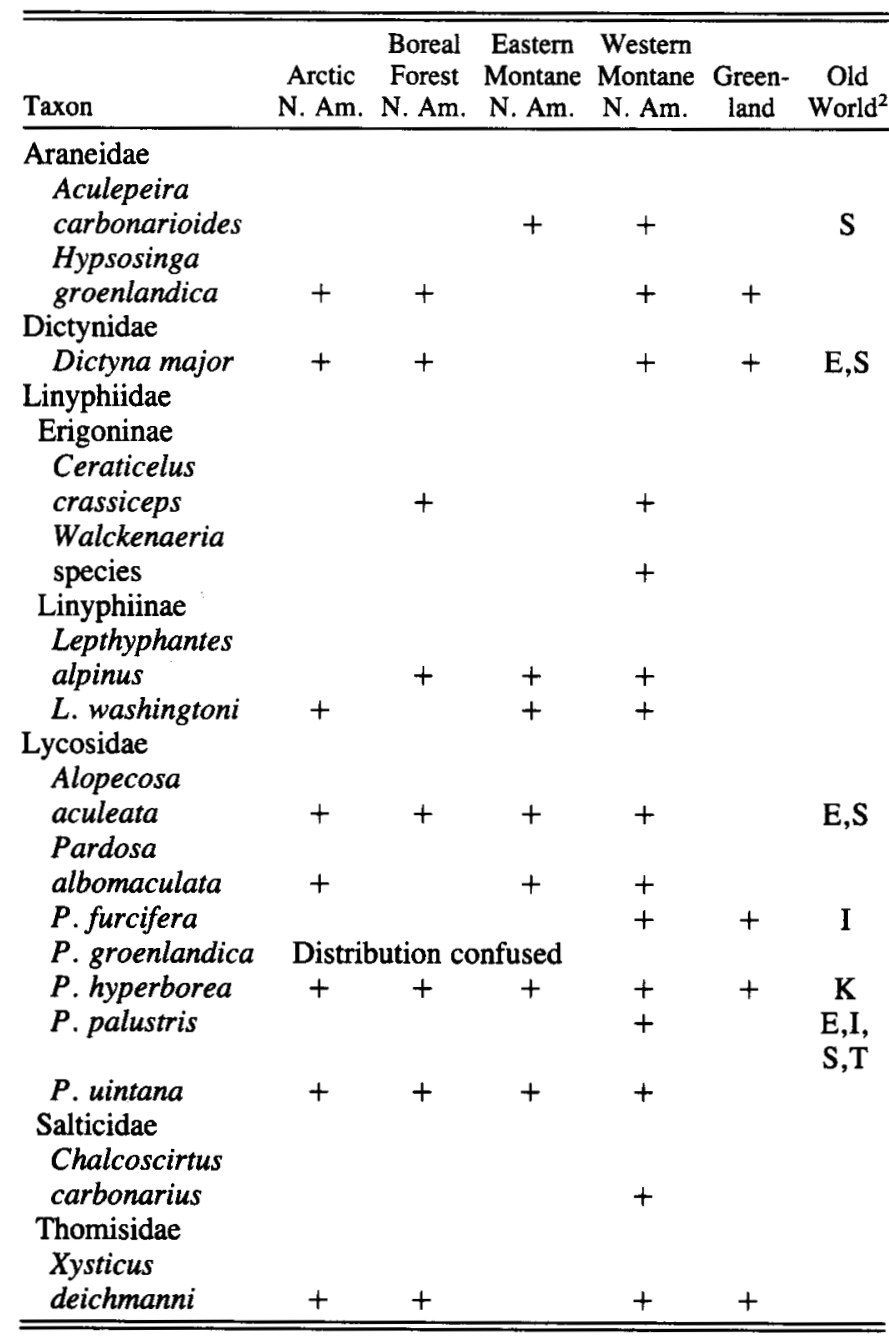

'Papers used in determining the distributions are: Braendegaard, 1946, 1958; Chamberlin and Gertsch, 1958; Chamberlin and Ivie, 1947; Dondale and Redner, 1978, 1979; Holm, 1970; Kronestedt, 1975; Levi, 1971, 1975, 1977; Lowrie and Dondale, 1981; Swann and Robey, 1975; Zorsch, 1937.

${ }^{2} \mathrm{E}=$ Europe, $\mathrm{I}=$ Iceland, $\mathrm{K}=$ Kola Peninsula, $\mathrm{S}=$ Siberia, $\mathrm{T}=$ Turkestan. are recorded, the majority are typically from montane, boreal and low arctic locations (Table 2). Only 3 species have not been found in nonmontane sites and are probably strictly montane. Of the purely montane species, Aculepeira carbonarioides dwell on boulder fields and cliff faces and Chalcoscirtus carbonarius on talus slopes. These habitats are more typical of montane environments. While most of the species from the alpine zone of Mt. Wrangell occur on lowland sites, together the species form a biota incorporating some species from both the low Arctic and the boreal forest, with a few montane specialists. As can be seen from Table 2, the ranges of these species tend to be extensive, some being palearctic as well as nearctic. Mani (1968) noted and summarized this situation well:

A fact of great biogeographical and ecological importance is that a great many of the species reported from Alaska-Yukon Territory are also known from the Canadian Rockies, the mountains in Colorado and Montana, from Labrador and from the Appalachian Region, especially the Presidential Range. Many of them extend moreover into the region of Beringia and Siberia, and occur also on the Altai Mountains and still others turn up even on the Fennoscandian mountains, in Novaya Zemlya and Greenland. [Mani, 1968:393.]

The family distribution is what one would expect in a northem alpine environment. Undoubtedly pitfall trapping would have uncovered other species and genera, and perhaps a few families such as Gnaphosidae and Hahniidae. This would not alter the dominant position of the Linyphiidae and Lycosidae. These two families are prominent in the temperate areas of the northern hemisphere (Kaston, 1981) and become predominant in the boreal, arctic, and montane regions (Gertsch, 1979).

\section{OTHER ARACHNIDS}

At sites $\mathrm{S} 837$ and $\mathrm{S} 840$ a male and immature phalangids of the species Liopilio yukon Cokendolpher were collected. The range of this species includes the west arctic coast of Alaska and the mountains of southeastern Alaska and the southern Yukon Territory (Cokendolpher, 1981). Trombidiiform mites were collected at sites $\mathbf{S 8 2 6}$ and $\mathbf{8 3 7}$. Undoubtedly mites form a common element of the fauna, but they were not specifically sought in this study.

\section{ACKNOWLEDGEMENTS}

We wish to thank the following specialists for identifications in the following groups: Linyphiidae - Dr. Richard Carter, University of Manitoba, Winnipeg; Lycosidae - Dr. Charles Dondale, Biosystematics Research Institute, Agriculture Canada, Ottawa; Opiliones Dr. James Cokendolpher, Texas Tech University, Lubbock; Dr. William Shear, Hampden-Sydney College, Virginia. These specialists have retained the specimens they identified. All other specimens are in the collection of Bruce Cutler.

\section{APPENDIX}

Habitat and localities of spider collections by collection number, United States legal description, latitude and longitude, and habitat.

S826: T1S, R6E, s. 11 , NE $1 / 4 ; 61^{\circ} 48^{\prime} \mathrm{N}, 144^{\circ} 16^{\prime} \mathrm{W}$; $975 \mathrm{~m}$ el; Cheshnina drainage; 13 June 1978; dwarf Betula and Salix, grasses by small lake.

S830: T1N, R6E, s. 26, SW1/4; 61 ${ }^{\circ} 50^{\prime} \mathrm{N}, 144^{\circ} 16^{\prime} \mathrm{W} ; 1300 \mathrm{~m}$ el; Cheshnina drainage; 9 June 1978; near stream, grasses and dwarf Betula.

S831: T1N, R6E, s. 27, NE $1 / 4 ; 61^{\circ} 50^{\prime} \mathrm{N}, 144^{\circ} 17^{\prime} \mathrm{W} ; 1675 \mathrm{~m}$ el; Cheshnina drainage; 6 June 1978; summit rock and adjacent vegetation.

S833: TIN, R7E, s. 31, SE $1 / 4 ; 61^{\circ} 19^{\prime} \mathrm{N}, 144^{\circ} 12^{\prime} \mathrm{W} ; 950 \mathrm{~m}$ el; Cheshnina drainage; 17 June 1978; on river bar. 
S834: T1N, R7E, s. $28, \mathrm{SW} / 1 / 4 ; 61^{\circ} 50^{\prime} \mathrm{N}, 144^{\circ} 09^{\prime} \mathrm{W} ; 1000 \mathrm{~m}$ el; Cheshnina drainage; 19 June 1978; lichen covered gravel and sand along river.

S835: T1N, R7E, s. $27, \mathrm{SW}^{1} / 4 ; 61^{\circ} 50^{\prime} \mathrm{N}, 144^{\circ} 07^{\prime} \mathrm{W} ; 1075 \mathrm{~m}$ el; Cheshnina drainage; 21 June 1978; sparse dwarf Salix, Epilobium, lichens along river.

S837: T3N, R5E, s. $28, \mathrm{SW}^{1 / 4} ;{ }^{\circ} 62^{\circ} 01^{\prime} \mathrm{N}, 144^{\circ} 30^{\prime} \mathrm{W} ; 1150 \mathrm{~m}$ el; Dadina drainage; 22 July 1978; Alnus thicket by stream.

S839: T2N, R6E, s. 8, SE $1 / 4 ; 61^{\circ} 58^{\prime} \mathrm{N}, 144^{\circ} 20^{\prime} \mathrm{W} ; 1400 \mathrm{~m}$ el; Chetaslina drainage; 12 July 1978 ; unvegetated boulders.

S840: T1N, R7E, s. 34, NW1/4; 61 ${ }^{\circ} 50^{\prime} \mathrm{N}, 144^{\circ} 07^{\prime} \mathrm{W} ; 1525 \mathrm{~m}$ el; Cheshnina drainage; 20 June 1978; under rock on cliff.

S850: T3N, R5E, s. 28, SW $1 / 4 ; 62^{\circ} 01^{\prime} \mathrm{N}, 144^{\circ} 30^{\prime} \mathrm{W} ; 1150 \mathrm{~m}$ el; Dadina drainage; 20 July 1978 ; rocky stream bed.

S852: see $\$ 839$.

S854: see $\$ 839$.

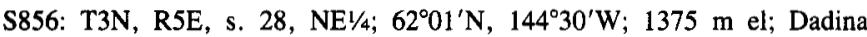
drainage; 20 July 1978; under rocks in rock slide.

S857: T2N, R5E, s. $34, \mathrm{SE}^{1 / 4} / 61^{\circ} 55^{\prime} \mathrm{N}, 144^{\circ} 27^{\prime} \mathrm{W} ; 850 \mathrm{~m}$ el; Chetaslina drainage, 5 July 1978; sparse lichens on gravel and silt along river edge.

S4: T1N, R1E, s. 5, SE $1 / 4 ; 61^{\circ} 54^{\prime} \mathrm{N}, 144^{\circ} 09^{\prime} \mathrm{W} ; 1900 \mathrm{~m}$ el; Cheshnina drainage; 10 July 1980; morainal rocks at glacier margin.

\section{REFERENCES}

BRAENDEGAARD, J. 1946. The spiders (Araneina) of East Greenland Meddelelser om Grønland 121:1-128.

1958. The Zoology of Iceland 54. Araneida. $113 \mathrm{p}$

CHAMBERLIN, R.V., and GERTSCH, W.J. 1958. The spider family Dictynidae in America north of Mexico. Bulletin of the American Museum of Natural History 116:1-152.

CHAMBERLIN, R.V., and IVIE, W. 1947. The spiders of Alaska. Bulletin of the University of Utah $37(10): 1-103$.

COKENDOLPHER, J.C. 1981. The harvestman genus Liopilio Schenkel (Opiliones: Phalangiidae). Journal of Arachnology 9:309-316.
DONDALE, C.D., and REDNER, J.H. 1978. The Insects and Arachnids of Canada. Part 5. The crab spiders of Canada and Alaska (Araneae: Philodromidae and Thomisidae). Ottawa: Department of Agriculture, Research Branch, Publication 1663. 255 p.

1979. Revision of the wolf spider genus Alopecosa Simon in North America (Araneae: Lycosidae). Canadian Entomologist 111:1033-1055.

GERTSCH, W.J. 1979. American Spiders. New York: Van Nostrand Reinhold. $274 \mathrm{p}$.

HOLM, A. 1970. Notes on spiders collected by the "Vega" expedition. Entomologica Scandinavica 1:188-208.

KASTON, B.J. 1981. Spiders of Connecticut. Connecticut State Geological and Natural History Survey, Bulletin 70.1020 p.

KRONESTEDT, T. 1975. Studies on species of holarctic Pardosa group (Araneae, Lycosidae) I. Zoologica Scripta 4:217-228.

LEVI, H.W. 1971. The orb-weaver genera Singa and Hypsosinga in America (Araneae: Araneidae). Psyche 78:229-256.

1975. Additional notes on the orb-weaver genera Araneus, Hypsosinga and Singa north of Mexico (Araneae: Araneidae). Psyche 82:265-274.

1977. The orb-weaver genera Metepeira, Kaira and Aculepeira in America north of Mexico (Araneae: Araneidae). Bulletin of the Museum of Comparative Zoology 148:185-238

LOWRIE, D.C., and DONDALE, C.D. 1981. A revision of the nigra group of the genus Pardosa in North America (Araneae, Lycosidae). Bulletin of the American Museum of Natural History 170:125-139.

MANI, M.S. 1968. Ecology and Biogeography of High Altitude Insects. The Hague: Junk N V Publisher. 527 p.

SALTMARCH, R. 1978. Mt. Wrangell: Landforms and Lifeforms of Its Southern and Western Flanks. Privately printed, St. Paul. 25 p.

SWANN, P.H., and ROBEY, C. 1975. A redescription of the North American jumping spider Chalcoscirtus carbonarius Emerton 1917. Bulletin of the British Arachnological Society 3:101-104.

ZORSCH, H. 1937. The spider genus Lepthyphantes in the United States. American Midland Naturalist 18:856-898. 